\title{
Influence of the acid erosion associated with dental bleaching in bovine enamel: In
}

\section{vitro study}

\author{
Influência da erosão ácida associadla ao clareamento dentário em esmalte bovino: Estudo in vitro \\ Influencia de la erosión ácida asociada con el blanqueamiento dental en el esmalte bovino: Estudio \\ in vitro
}

Received: 04/08/2021 | Reviewed: 04/14/2021 | Accept: 04/23/2021 | Published: 05/08/2021

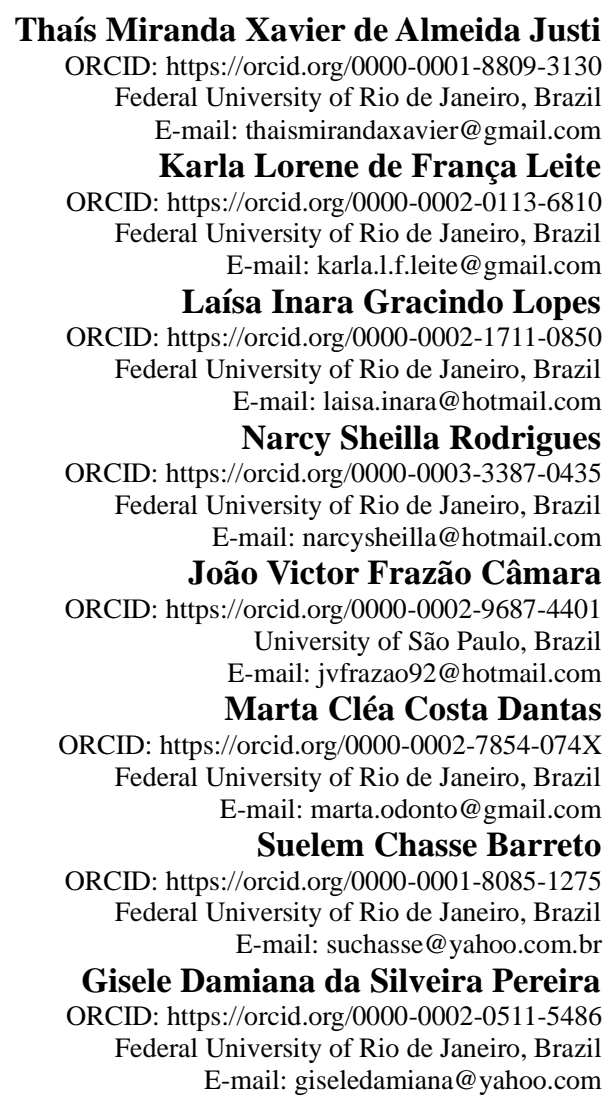

\begin{abstract}
Objective: To evaluate the influence of acid erosion caused by the daily intake of lemon juice or apple cider vinegar, associated with immediate dental whitening, on bovine enamel. Materials and Methods: 30 bovine teeth were sectioned to obtain enamel blocks and were distributed into three groups $(\mathrm{n}=10)$ : G1 - Tooth whitening with $35 \%$ hydrogen peroxide; G2- Tooth whitening with $35 \%$ hydrogen peroxide + lemon juice and G3 - Tooth whitening with $35 \%$ hydrogen peroxide + apple cider vinegar. Treatments were performed for 21 days, the varnish was removed and the analysis of loss of structure and surface roughness were performed by means of non-contact 3D Confocal Chromatic Profilometer. The roughness data obtained were analyzed by Kruskal-Wallis and Mann-Whitney nonparametric tests. Results: All groups exhibited greater roughness $(\mathrm{Sa})$ on the side exposed to the treatments $(\mathrm{G} 1=$ $3.17 \mathrm{~b} ; \mathrm{G} 2=4.17 \mathrm{~b} ; \mathrm{G} 3=3.99 \mathrm{~b})$ compared to the unexposed side $(\mathrm{G} 1=2.55 \mathrm{a} ; \mathrm{G} 2=3.94 \mathrm{a} ; \mathrm{G} 3=2.40 \mathrm{a})$. There was a statistically significant difference among the groups evaluated, being G1 (3.17A) <G3 (3.99C) <G2 (4.17B). Conclusion: $35 \%$ hydrogen peroxide has the least erosive potential when compared to its association with vinegar and to lemon juice.
\end{abstract}

Keywords: Tooth erosion; Dental enamel; Citric acid; Acetic acid; Tooth whitening.

\section{Resumo}

Objetivo: Avaliar a influência da erosão ácida causada pela ingestão diária de suco de limão ou vinagre de maçã, associada ao clareamento dental imediato, no esmalte bovino. Materiais e Métodos: 30 dentes bovinos foram seccionados para obtenção de blocos de esmalte e distribuídos em três grupos $(n=10)$ : G1- Clareamento dentário com 
peróxido de hidrogênio a 35\%; G2- Clareamento dentário com peróxido de hidrogênio 35\% + suco de limão e G3 Clareamento dental com peróxido de hidrogênio 35\% + vinagre de maçã. Os tratamentos foram realizados durante 21 dias, o verniz foi removido e as análises de perda de estrutura e rugosidade superficial foram realizadas por meio de Profilômetro Cromático Confocal 3D sem contato. Os dados de rugosidade obtidos foram analisados pelos testes não paramétricos de Kruskal-Wallis e Mann-Whitney. Resultados: Todos os grupos exibiram maior rugosidade (Sa) do lado exposto aos tratamentos $(\mathrm{G} 1=3,17 \mathrm{~b} ; \mathrm{G} 2=4,17 \mathrm{~b} ; \mathrm{G} 3=3,99 \mathrm{~b})$ em relação ao lado não exposto $(\mathrm{G} 1=2,55 \mathrm{a} ; \mathrm{G} 2$ $=3,94 \mathrm{a} ; \mathrm{G} 3=2,40 \mathrm{a})$. Houve diferença estatisticamente significativa entre os grupos avaliados, sendo G1 (3,17A) <G3 (3,99C) <G2 (4,17B). Conclusão: O peróxido de hidrogênio a 35\% apresentou menor potencial erosivo quando comparado ao vinagre e ao suco de limão.

Palavras-chave: Erosão dentária; Esmalte dentário; Ácido cítrico; Ácido acético; Clareamento dentário.

\section{Resumen}

Objetivo: Evaluar la influencia de la erosión ácida provocada por la ingesta diaria de jugo de limón o vinagre de sidra de manzana, asociada al blanqueamiento dental inmediato, sobre el esmalte bovino. Materiales y Métodos: Se seccionaron 30 dientes de bovino para obtener bloques de esmalte y se distribuyeron en tres grupos $(n=10)$ : G1Blanqueamiento dental con peróxido de hidrógeno al 35\%; G2- Blanqueamiento dental con peróxido de hidrógeno al $35 \%$ + jugo de limón y G3 - Blanqueamiento dental con peróxido de hidrógeno al 35\% + vinagre de sidra de manzana. Los tratamientos se realizaron durante 21 días, se eliminó el barniz y se realizó el análisis de pérdida de estructura y rugosidad superficial mediante un Perfilómetro Cromático Confocal 3D sin contacto. Los datos de rugosidad obtenidos se analizaron mediante pruebas no paramétricas de Kruskal-Wallis y Mann-Whitney. Resultados: Todos los grupos mostraron mayor rugosidad $(\mathrm{Sa})$ en el lado expuesto a los tratamientos $(\mathrm{G} 1=3.17 \mathrm{~b} ; \mathrm{G} 2=4.17 \mathrm{~b} ; \mathrm{G} 3$ $=3.99 \mathrm{~b})$ en relación al lado no expuesto $(\mathrm{G} 1=2.55 \mathrm{a} ; \mathrm{G} 2=3.94 \mathrm{a} ; \mathrm{G} 3=2,40 \mathrm{a})$. Hubo una diferencia estadísticamente significativa entre los grupos evaluados, con G1 (3.17A) <G3 (3.99C) <G2 (4.17B). Conclusión: El peróxido de hidrógeno al 35\% mostró menos potencial erosivo en comparación con el vinagre y el jugo de limón.

Palabras clave: Erosión dental; Esmalte dental; Ácido cítrico; Ácido acético; Blanqueamiento dental.

\section{Introduction}

Although bleaching is considered a conservative treatment, tooth surface microhardness may present changes with the application of bleaching agents due to substance loss, causing a deleterious effect on tooth enamel topography (Dey et al., 2016; Liporoni et al., 2020). Conversely, in terms of enamel thickness, it may be said that the harmful effects are directly proportional to the concentration of the bleaching agent (Dey et al., 2016).

It is worth noting that individuals searching for tooth bleaching also chose peculiar eating habits, aiming at a healthier lifestyle. However, some foods consumed in these diets may somehow interfere with tooth structure due to their low pH values (Xing \& Xuedong, 2020). It may be mentioned, for instance, the intake of apple vinegar or lime juice during fasting, which many people have been doing lately. Concomitantly, there has been an increased prevalence of erosive lesions in enamel and dentin due to changes in nutritional parameters associated with behavioral and environmental habits (Dey et al., 2016; Zohoori \& Duckworth, 2020).

The acidic $\mathrm{pH}$ of these beverages may demineralize the tooth structure, causing enamel erosion (Zohoori \& Duckworth, 2020; Zanet et al., 2009). The condition of dental erosion is defined as the loss of tooth structure related to acid, which does not involve microorganisms (Zohoori \& Duckworth, 2020; Kanzow et al., 2016). Saliva can partially reverse these changes because of its low pH (Fernandes et al., 2020) but, depending on the frequency of intake, enamel damages occur and may reach the dentin. Tooth sensitivity, pain, and color change are only a few of the consequences of beverages with low $\mathrm{pH}$, resulting in decreased microhardness and increased tooth roughness (Zanet et al., 2009; Mosaico \& Casu, 2018).

Considering the aforementioned, this study aimed to assess the influence of using an acidic liquid diet based on apple vinegar or lime juice associated with immediate tooth bleaching, on the surface roughness of bovine enamel. The null hypothesis tested was that the treatments proposed would not change enamel surface topography. 


\section{Methodology}

\section{Materials}

This in vitro study used the Whiteness HP Maxx bleaching gel and, for the acidic liquid diet, concentrated lime juice and apple vinegar were used. Table 1 describes the commercial brands, compositions, $\mathrm{pH}$, and manufacturers.

Table 1: Trademark, composition, $\mathrm{pH}$ and manufacturers of the materials used in the experiment.

\begin{tabular}{|c|c|c|c|}
\hline COMMERCIAL BRAND & COMPOSITION & pH & MANUFACTURER \\
\hline 35\% Whiteness HP Maxx & $\begin{array}{l}35 \% \text { hydrogen peroxide, thickeners, dye } \\
\text { mixture, glycol, inorganic load, deionized } \\
\text { water. }\end{array}$ & $\begin{array}{c}\text { Neutral } \\
\text { (6.0 to } 7.0)\end{array}$ & $\begin{array}{c}\text { FGM - Joinville, SC - } \\
\text { Brazil. }\end{array}$ \\
\hline Artificial Saliva & $\begin{array}{l}\text { Calcium solution, nitrate solution, water } \\
\text { molecules, sodium hypophosphate, potassium } \\
\text { chloride solution, tris (hydroxymethyl) } \\
\text { aminomethane, fluoride solution }\end{array}$ & $\begin{array}{l}\text { Neutral } \\
\text { (6.0 to } 7.0 \text { ) }\end{array}$ & $\begin{array}{l}\text { UFRJ - CCMN - } \\
\text { Department of } \\
\text { Biochemistry, Rio de } \\
\text { Janeiro - RJ, Brazil. }\end{array}$ \\
\hline Apple Vinegar & $\begin{array}{c}\text { Components in every } 750 \mathrm{~mL} \text { : Unit } \% \text { - 99.36\% } \\
\text { Acetic Acid (volatile acidity) - } 4.0 \mathrm{~g} / 100 \mathrm{ml} \text {; } \\
\text { Calories (Kcal/100 g) - } 1.0 \mathrm{Kcal} / \mathrm{g} \text {; Potassium } \\
\text { Sulfates } 1.0 \mathrm{~g} / \mathrm{l} \mathrm{SO} 2 \mathrm{mg}-20 \% \text { Grey-.0.10 g/l; } \\
\text { Reduced dry extract -.0.54 g/l; Total lipids -. } 0.02 \\
\mathrm{~g} / \mathrm{l} .\end{array}$ & Acid (2.44) & $\begin{array}{c}\text { Castelo }^{\mathrm{TM}} \text { since 1903, SP- } \\
\text { Brazil. }\end{array}$ \\
\hline Lime Juice & $\begin{array}{c}\text { Water, concentrated lime juice, natural lime } \\
\text { aroma, lime essential oil, INS300 and INS224 } \\
\text { antioxidants, INS211 preservative, and INS171 } \\
\text { dye. }\end{array}$ & Acid (2.4) & $\begin{array}{c}\text { Castelo }^{\mathrm{TM}} \text { since } 1903, \mathrm{SP}- \\
\text { Brazil. }\end{array}$ \\
\hline
\end{tabular}

Source: Authors.

\section{Obtaining, cleaning and storing the teeth}

Thirty healthy bovine incisors were used (Yassen, 2011) (Frigorífico Mondelli, Indústria de Alimentos S/A, Santa Teresa, Bauru, SP, Brazil) and assessed with a 4x magnifying glass (Bioart, São Carlos, SP, Brazil) to detect cracks. The teeth were stored for one month in a $0.1 \%$ thymol solution (UFRJ- CCMN- Department of Biochemistry, Rio de Janeiro, RJ, Brazil) with a pH of 7 for disinfection until starting the cleaning of external surfaces with the Cavitron ultrasound system (Dentsply, Petrópolis, RJ, Brazil) and periodontal curettes (Gracey, Hu-Friedy, Chicago, Illinois, USA). The teeth were stored in distilled water until the preparation of surfaces.

\section{Sectioning, flattening, and polishing the buccal surface on the enamel}

The root portion was separated from the crown portion with a perpendicular section along the tooth axis, close to the amelocemental junction, using a double-sided diamond disc (American Burrs, Palhoça, SC, Brazil) assembled in a straight piece.

Next, the buccal surfaces of the samples were sanded with \#320, \#400, \#600, and \#1200 silicon carbide (SiC) sandpapers (3M do Brasil, Sumaré, SP, Brazil) in a water-cooled electric rotary polisher (Aropol VV, Arotec, Cotia, SP, Brazil) to obtain a plain enamel surface. An average of two minutes was spent for each file, polishing with diamond paste with 
granulations of 3, 0.5, and $0.25 \mu \mathrm{m}$ (AROTEC Ind. Com, SP, Brazil) and felt discs in a polisher, and water cooling. Between each file and paste granulation, the samples were taken to an ultrasound vat (Ultrasound Ultrason 1440 D- Odontobrás Ind. E Com. Med. Odont. Ltda, Rio Preto, SP, Brazil) for 10 minutes to remove debris.

\section{Determining the assessment area with a profilometer}

To determine the area used for applying the surface treatments and profilometer assessment, a square was highlighted in the center of the flattened enamel buccal surface, which was polished and free of cracks, with dimensions of $6 \mathrm{~mm} \times 6 \mathrm{~mm} \times$ $2 \mathrm{~mm}$. This was performed with the double-sided diamond disc (American Burrs, Palhoça, SC, Brazil) assembled in a straight piece. Enamel-dentin blocks from this surface were obtained, with an area of $36 \mathrm{~mm}^{2}$. The samples were inserted in PVC devices and fixed with hot wax (Utilidade, Coltene, RJ, Brazil). Before the erosive challenge, half of each sample (initial area of the enamel surface) was covered with an acid-resistant varnish (nail varnish - Colorama, L'Oreal Brasil, Rio de Janeiro, RJ, Brazil) (Figure 5). This provided control to each group (G1a, G2a, and G3a), considering that the area covered with the varnish was not subjected to the erosive cycle (Alexandria et al., 2017). Later, the tooth fragments remained immersed in distilled and deionized water for 24 hours. At the end of this period, the fragments were dried with an absorbent paper, identified, and randomly distributed among the experimental groups.

\section{Experimental groups}

After surface polishing and varnish application in half of each specimen, the tooth blocks were randomly distributed in three experimental groups $(\mathrm{n}=10)$ according to the respective treatment, which is described next:

Group 1 - Ten tooth fragments were subjected to immediate bleaching with the Whiteness HP Maxx bleaching gel (35\% hydrogen peroxide), once a week, for three weeks;

Group 2 - Ten tooth fragments were subjected to immediate bleaching with the Whiteness HP Maxx bleaching gel (35\% hydrogen peroxide), once a week, for three weeks, associated with daily lime juice immersion;

Group 3 - Ten tooth fragments were subjected to immediate bleaching with the Whiteness HP Maxx bleaching gel (35\% hydrogen peroxide), once a week, for three weeks, associated with daily apple vinegar immersion.

During the experiment, all tooth fragments remained in three organizing plastic boxes, immersed in $25 \mathrm{ml}$ of artificial saliva that was changed daily (UFRJ- CCMN - Department of Biochemistry, Rio de Janeiro, RJ, Brazil), and removed from this solution only for applying the surface treatment (Dey et al., 2016).

\section{Immersion in acidic food beverage}

The tooth fragments were immersed, depending on the group, individually in $25 \mathrm{ml}$ of apple vinegar with a pH of 2.44 (Castelo $^{\mathrm{TM}}$, SP, Brazil) for two minutes, and in $25 \mathrm{ml}$ of lime juice with a pH of 2.4 (Castelo $^{\mathrm{TM}}$, SP, Brazil) for two minutes, under mild agitation, once a day, for three weeks. Later, the fragments were washed with distilled water for one minute, dried, and stored in artificial saliva for the time remaining (Rios et al., 2018).

\section{Bleaching gel application}

The immediate bleaching of enamel surfaces was performed with the $35 \%$ hydrogen peroxide Whiteness HP Maxx bleaching gel (FGM Produtos Odontológicos Ltda, Joinville, SC, Brazil). Bleaching was performed simulating immediate bleaching and according to a previous study (Mushashe et al., 2018).

Tooth bleaching was performed in vitro once a week, according to the manufacturer's instructions, for three consecutive weeks. After manipulation, the gel was applied under the exposed enamel surface homogeneously, in a thickness 
of 0.5 to $1.0 \mathrm{~mm}$ (Mondelli et al., 2015; Kutuk et al., 2019), and remained under the tooth surface for 15 minutes. This step was repeated two more times, resulting in three applications. At the end of the procedure, the fragments were washed with water/air spray and stored again in $25 \mathrm{ml}$ of artificial saliva (UFRJ - CCMN - Department of Biochemistry, Rio de Janeiro, RJ, Brazil) for the time remaining.

\section{Profilometry analysis}

The non-contact 3D profilometry technique was used to determine: i) surface roughness (linear-Ra and volumetric-Sa) and ii) structure loss (SL- grade) after the treatment (Alexandria et al., 2017). Linear surface roughness (Ra) may be defined as the mean deviation of a profile from its mean line. The linear surface roughness ( $\mathrm{Ra}$ ) of the buccal aspect was measured in the samples in the regions not exposed (isolated with nail polish) and exposed (subjected to erosion), aided by a non-contact 3D Chromatic Confocal Profilometer (Nanovea PS50 Optical, NANOVEA Inc., Irvine, CA, USA). The capture was performed with a chromatic confocal sensor with an axial white light source at a scanning speed of $2 \mu \mathrm{m} / \mathrm{s}$ and a refraction index of 10000 $\mathrm{Hz}$. The following parameters were analyzed: linear roughness (Ra), volumetric surface roughness (Sa), and structure loss (SLgrade).

Volumetric surface roughness $(\mathrm{Sa})$ represents the analysis of a larger extension in the surface area and not only one tracing such as Ra. However, the concept of grade (SL) represents the difference in height between the part exposed and not exposed of the sample, determining the degree of structure loss. The specimens were fixed in an acrylic base parallel to the surface of the equipment to perform three readings per sample. The Ra and Sa values for each sample were determined by the arithmetic mean of the three readings.

\section{Statistical analysis}

For the roughness tests, the data were analyzed with the Kruskal-Wallis non-parametric and Mann-Whitney statistical tests. All data were submitted to the IBM SPSSS software and the significance level was $p<0.05$.

\section{Results}

The quantitative assessment of the surface roughness obtained with the profilometer allowed obtaining the degree of topographic change caused by immediate bleaching and its association with apple vinegar and lime juice. Figure 1 represents the samples of G1 in which one half was protected with nail varnish and the other half was exposed to immediate bleaching. The graph shows red and yellow areas representing peak areas, while green and blue are valley areas where there was some degree of structure loss. Thus, smaller changes were observed in the surface roughness of the group that received only immediate bleaching. 
Figure 1: Topographic surface of the whitening group.

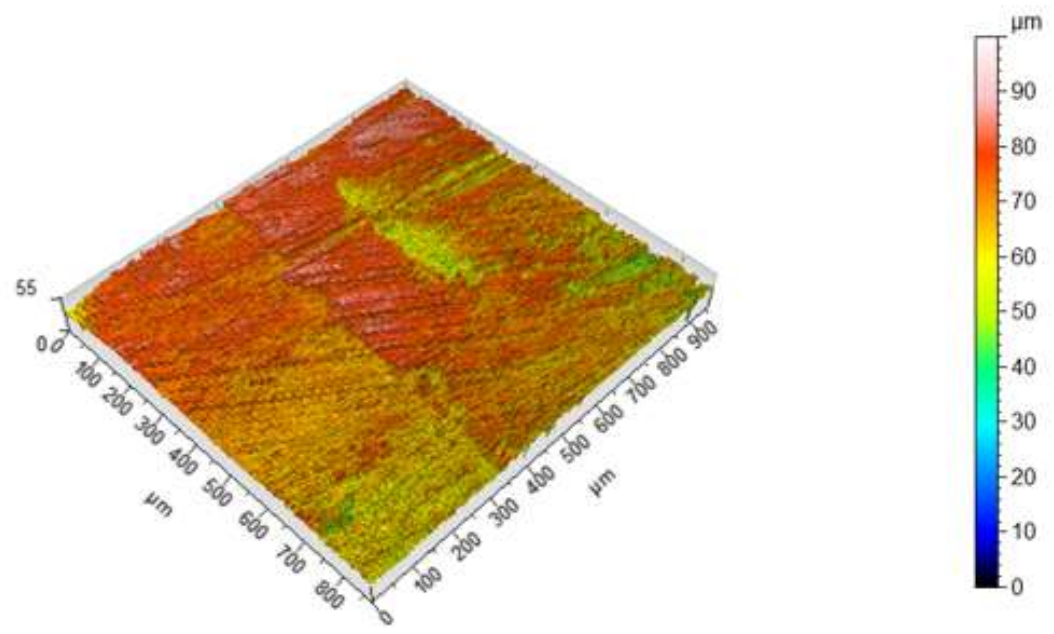

Source: Authors.

In turn, G3 - apple vinegar (Figure 2) - showed the prevalence of a deeper surface in the part of the sample subjected to the erosive challenge in comparison to the other half that was protected. This aspect is even more apparent in G2 - lime juice - , also showing greater depth in the exposed area (Figure 3).

Figure 2: Topographic surface of the vinegar group.
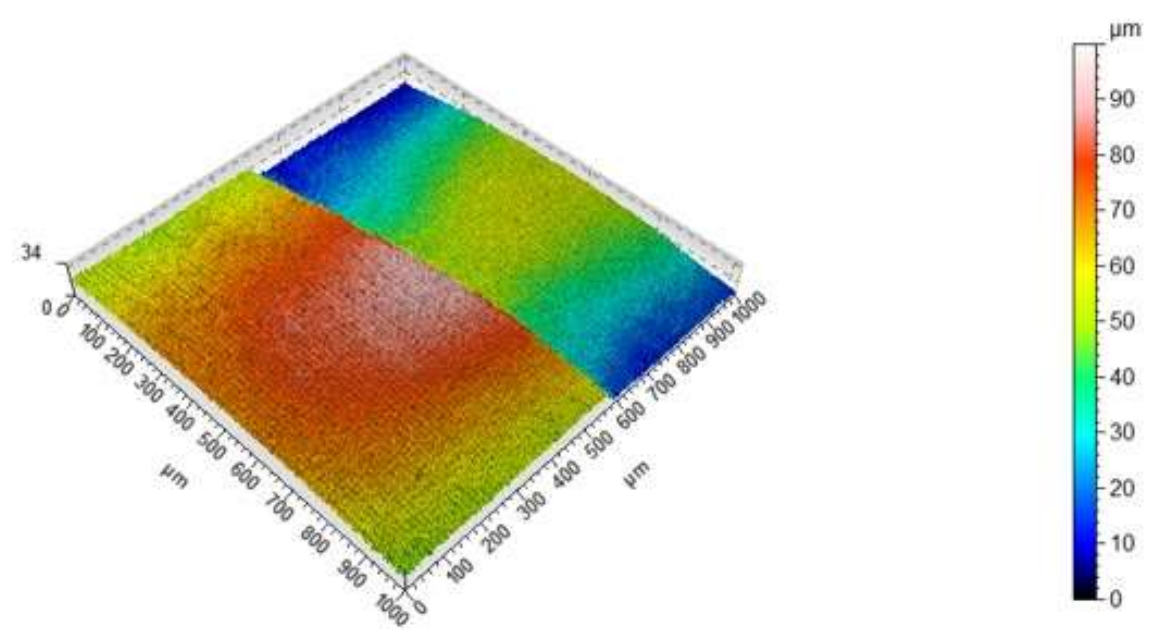

Source: Authors. 
Figure 3: Topographic surface of the lemon group.

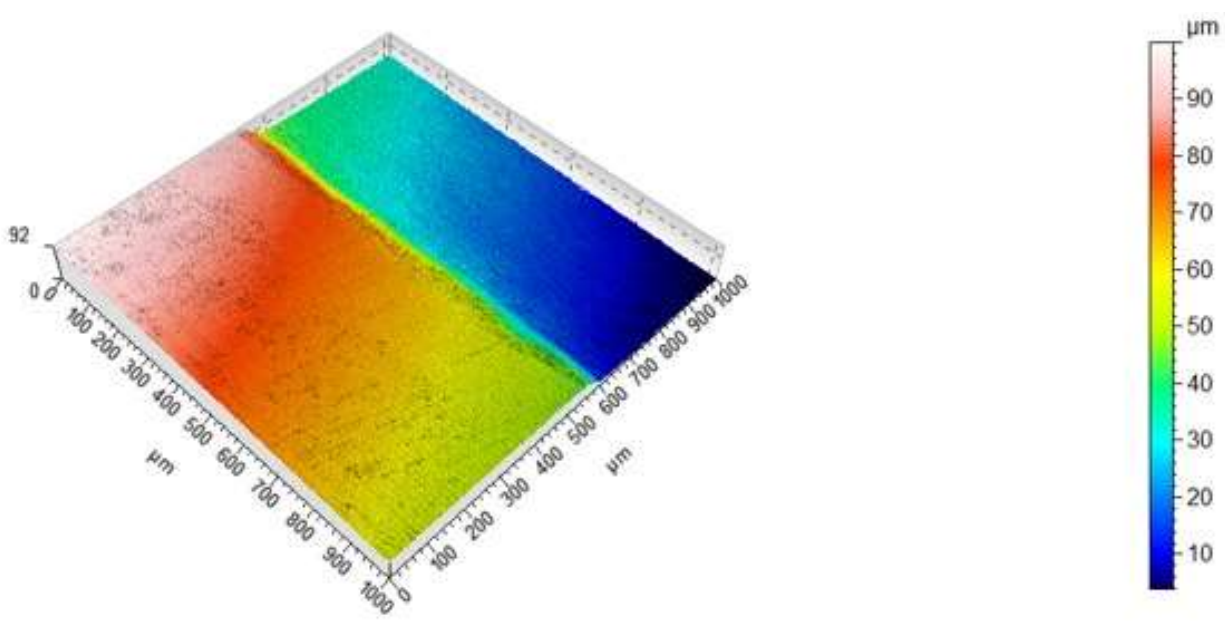

Source: Authors.

Roughness data were analyzed with the Kruskal-Wallis non-parametric and Mann-Whitney tests, which showed a statistical difference in surface roughness in all groups assessed. Tables 2, 3, 4 and 5 show the enamel surface roughness values obtained with non-contact profilometry for the $\mathrm{Ra}, \mathrm{Sa}$, and Grade variables of the experimental groups after the erosive challenge.

The Ra (Table 2) is a linear measure, therefore it analyzes only one tracing. Statistically, a higher linear roughness was observed in all the groups subjected to acid erosion $(\mathrm{G} 1=0.91 \mathrm{~b} ; \mathrm{G} 2=0.72 \mathrm{~b} ; \mathrm{G} 3=0.66 \mathrm{~b})$ when compared to the side of the sample that was not exposed to surface treatments (G1a=0.68 a; G2a=0.50 a; G3a= $0.55 a)$.

Table 2: Ra values of the experimental groups after erosion challenge.

\begin{tabular}{c|c|c|c|c|c|c}
\hline \multirow{2}{*}{ Groups } & \multicolumn{6}{|c}{ Ra } \\
\cline { 2 - 7 } & \multicolumn{3}{|c|}{ Sound Surface } & \multicolumn{3}{c}{ Treated Surface } \\
\cline { 2 - 7 } Whitening & Med & Mn & Max & Med & Min & Max \\
\cline { 2 - 7 } Lemon & $0,68 \mathrm{Aa}$ & 0,41 & 1,19 & $0,91 \mathrm{Ab}$ & 0,50 & 1,28 \\
Vinegar & $0,50 \mathrm{Aa}$ & 0,36 & 1,23 & $0,72 \mathrm{Ab}$ & 0,43 & 1,17 \\
& $0,55 \mathrm{Aa}$ & 0,31 & 0,72 & $0,66 \mathrm{Bb}$ & 0,43 & 1,07 \\
\hline
\end{tabular}

Med: median; Min: minimum; Max: maximum. Different capital letters in the same column - significant difference between groups. Different lowercase letters - significant difference between the healthy and treated surfaces $(\mathrm{p}<0.05)$. The data were analyzed using the Kruskal-Wallis and Mann-Whitney test. Source: Authors.

The Sa (Tables 3 and 4), in turn, is a volumetric measure, therefore it analyzes a higher surface extension and not only one tracing, thus minimizing the likelihood of a crack or defect in the enamel to compromise the analysis results. Again, all groups showed higher roughness on the side exposed to the treatments $(\mathrm{G} 1=3.17 \mathrm{~b} ; \mathrm{G} 2=4.17 \mathrm{~b} ; \mathrm{G} 3=3.99 \mathrm{~b})$ when compared to the side not exposed (G1a=2.55 a; G2a= $3.94 \mathrm{a} ; \mathrm{G} 3 \mathrm{a}=2.40 \mathrm{a})$ (Table 2). 
Table 3: Sa values of the experimental groups after erosion challenge. Evaluation between healthy and treated surfaces.

\begin{tabular}{c|c|c|c|c|c|c}
\hline \multirow{2}{*}{ Groups } & \multicolumn{5}{c}{ Sa } \\
\cline { 2 - 7 } & \multicolumn{3}{|c|}{ Sound Surface } & \multicolumn{3}{c}{ Treated Surface } \\
\cline { 2 - 7 } & Med & Min & Max & Med & Min & Max \\
\cline { 2 - 7 } Whitening & $2,55 \mathrm{a}$ & 0,84 & 4,63 & $3,17 \mathrm{~b}$ & 1,25 & 5,97 \\
Lemon & $3,94 \mathrm{a}$ & 0,67 & 9,41 & $4,17 \mathrm{~b}$ & 1,21 & 19,46 \\
Vinegar & $2,40 \mathrm{a}$ & 1,48 & 5,64 & $3,99 \mathrm{~b}$ & 1,81 & 5,27 \\
\hline
\end{tabular}

Med: median; Min: minimum; Max: maximum. Different lowercase letters represent a statistical difference between the healthy and treated surfaces $(\mathrm{p}<0.05)$. The data were analyzed using the Kruskal-Wallis and Mann-Whitney tests. Source: Authors.

The assessment between groups (Table 4) showed a statistically significant difference between the three groups assessed, with $\mathrm{G} 1(3.17 \mathrm{~A})<\mathrm{G} 3(3.99 \mathrm{C})<\mathrm{G} 2$ (4.17 B), which suggests that bleaching associated with lime juice immersion caused the highest surface roughness of the samples assessed.

Table 4: Sa values of the experimental groups after erosion challenge. Evaluation between groups.

\begin{tabular}{c|c|c|c}
\hline \multirow{2}{*}{ Groups } & \multicolumn{3}{|c}{ Sa } \\
\cline { 2 - 4 } & \multicolumn{3}{|c}{ Treated Surface } \\
\cline { 2 - 4 } Whitening & Med & Min & Max \\
\cline { 2 - 4 } Lemon & $3,17 \mathrm{~A}$ & 1,25 & 5,97 \\
Vinegar & 4,17B & 1,21 & 19,46 \\
& $3,99 \mathrm{C}$ & 1,81 & 5,27 \\
\hline
\end{tabular}

Med: median; Min: minimum; Max: maximum. Different capital letters in the same column mean a statistically significant difference between groups, $(\mathrm{p}<0.05)$. The data were analyzed using the Kruskal-Wallis and Mann-Whitney tests. Source: Authors.

The grade values (Table 5) represent the difference in height between the areas exposed and not exposed. The higher the grade value, the higher the structure loss. The G2 (Bleaching + Lime Juice) presented the highest grade value (67.75B), thus suggesting that lime has the highest erosive potential when compared to vinegar $(\mathrm{G} 3=41.40 \mathrm{C})$ and immediate bleaching $(\mathrm{G} 1=29.80 \mathrm{~A})$. Additionally, immediate bleaching presented the lowest grade value, suggesting that, when applied alone, it has the lowest erosive potential when compared to its association with vinegar and especially lime juice. 
Table 5: Step values of the experimental groups after erosion challenge.

\begin{tabular}{|c|c|c|c|}
\hline \multirow{2}{*}{ Groups } & \multicolumn{3}{|c|}{ Step } \\
\hline & Med & Min & Max \\
\hline Whitening & $29,80 \mathrm{~A}$ & 9,74 & 41,25 \\
\hline Lemon & $67,75 \mathrm{~B}$ & 41,22 & 153,71 \\
\hline Vinegar & $41,40 \mathrm{C}$ & 18,26 & 72,18 \\
\hline
\end{tabular}

Med: median; Min: minimum; Max: maximum. Different capital letters in the same column mean a statistically significant difference between groups $(\mathrm{p}<0.05)$. The data were analyzed using the Kruskal-Wallis and Mann-Whitney tests. Source: Authors.

\section{Discussion}

The null hypothesis tested was rejected because there was a difference in tooth enamel topography after the erosive challenges. Tooth surface wear, which is currently a great concern, is affected by modifiable factors that, depending on intensity and duration, cause different levels of tissue losses (Oliveira et al., 2016). There are four acknowledged types of tooth wear: abrasion, attrition, abfraction, and erosion. The first three occur due to mechanical forces, while erosion occurs by chemical reactions caused by acids (Lussi et al., 2019).

Dental erosion is a clinical term used to describe the results of a pathological, progressive, and irreversible localized loss of dental hard tissue due to a chemical process, without bacterial involvement (Canto et al., 2020). In the initial stages, erosion changes the physical properties of teeth, including changes in microhardness and surface roughness (Oliveira et al., 2017). Roughness, which is the focus of this study, is the measure of relief variations of a surface, that is, the vertical deviation of an actual surface from its optimal shape.

Enamel surface roughness is assessed with profilometers and roughness meters, with or without contact, or microscopic scanning probes such as the atomic force microscope and the tunneling microscope, and both have advantages and limitations. In devices that use the contact technique, the load applied, however small, changes the geometry of the profilometer tip and consequently the profile analyzed, which affects the reading of surface wear (Costa, 2013). In this study, surface roughness was measured with the help of a non-contact 3D Chromatic Confocal Profilometer. Surface profilometry is used to quantify dental tissue loss relative to an untreated reference area (Canto et al., 2020). This test was selected for the present study because using optical profilometry allows assessing surfaces subjected to wear, which spacing between the irregularities has minimal dimensions of micrometer fractions $(\mu \mathrm{m})$ and minimum roughness heights ranging from 0.01 to $0.001 \mu \mathrm{m}$, relative to microroughness (Costa, 2013).

Moreover, the effect of several enamel erosion conditions with satisfactory reproducibility of results of in vitro studies has been extensively analyzed with bovine incisors as substitutes for human teeth because they present a morpho-histological similarity to them and similar laboratory test results, which can be used to assess the influence of several treatments on tooth enamel. Due to the rough surface, flattening was performed in this study to standardize the initial smoothness. This procedure aims to reduce the variation between the samples, despite removing the enamel surface layer that is more resistant to acid action. However, this procedure did not interfere with the results because it was used in all the groups assessed (Yassen et al., 2011).

Smile esthetics is highly important to patients, especially tooth color, which often consolidates the bleaching of vital teeth as the first-choice treatment in the dental practice (Mondelli et al., 2015; Tin-Oo et al., 2011; Bersezio et al., 2017). This 
procedure aims to use hydrogen peroxide and/or carbamide peroxide compounds in different presentations, concentrations, and application times/types.1 Although extensively promoted, the oxidizing effect of the procedure on dental tissues should be considered (Dey et al., 2016; Liporoni et al., 2020; Tin-Oo et al., 2011; Bersezio et al., 2017) because microstructural changes, such as increased porosity and the formation of valleys, were observed on enamel surfaces after the exposure to bleaching, as well as a mild reduction in surface hardness (Liporoni et al., 2020; Azrak et al., 2010; Abouassi et al., 2011; Sa et al., 2013; Omar et al., 2019).

This information agrees with the results found in this study, which observed that roughness (linear and volumetric) was statistically higher in the group that received immediate bleaching (G1) than in the group that did not receive such treatment (G1a). There was also a statistically significant increase in the height difference between the areas exposed and not exposed, with grade formation, which suggests structure loss in this substrate, although it was the smallest one observed among the conditions assessed.

Bleaching gels with higher peroxide concentrations (30-35\%) are used in professional bleaching sessions under the direct supervision of a dentist. The high peroxide concentration in the bleaching gel, such as $35 \%$ hydrogen peroxide, results in a faster whitening effect but it also has a potentially higher risk of adverse effects such as tooth sensitivity and morphological changes in the enamel (Dey et al., 2016; Ayres et al., 2016; Vieira et al., 2020).

The bleaching technique is acidic and may demineralize the enamel. When hydrogen peroxide degrades, it releases free radicals (byproducts of the hydroxyl $\mathrm{OH}$ and perihydroxyl $\mathrm{OH} 2$ reaction) that can diffuse through the tooth enamel structure and oxidize particles responsible for enamel darkening in both intraprismatic region and prism peripheries, converting them into smaller molecules and changing the optical properties of the tooth substrate (Liporoni et al., 2020; Vieira et al., 2020). It is still not well established how free radicals diffuse but their infiltration through the enamel structure is associated with the increased permeability of this tissue. However, when carbamide peroxide degrades, it releases byproducts such as urea (CH4N2O). Urea, in turn, helps to neutralize the acidic $\mathrm{pH}$ of the bleaching technique, reducing or even preventing tooth enamel demineralization. This study used hydrogen peroxide as the bleaching agent and its activity regarding enamel topography changes agrees with its action mode described in the literature (Mushashe et al., 2018).

Moreover, the higher the concentration of the bleaching agent used, such as the high concentration in the present study, the higher the likelihood of enamel changes due to the higher level of peroxide action. This results in the increased permeability of dental hard tissues relative to the bleaching agent and free radicals (Dey et al., 2016; Liporoni et al., 2020; Vieira et al., 2020).

The acids responsible for dental erosion come from intrinsic sources (such as eating disorders or gastric reflux) or extrinsic ones. An important extrinsic factor responsible for dental erosion is the high consumption of carbonated beverages and the daily ingestion of acidic beverages and foods, which frequency has been increasing with the lifestyle changes of the contemporary world (Zohoori et al., 2020). The demineralization process is the same described for caries but the acid provided by foods and beverages affects a much larger enamel surface area (Zohoori et al., 2020).

Due to the culture of esthetic search, many people looking for tooth bleaching still chose peculiar eating habits such as consuming apple vinegar or lime juice during fasting. Thus, these acidic beverages were also tested associated with tooth bleaching and the results obtained showed statistically significant differences among the three groups assessed, with G1 (3.17 A) < G3 (3.99 C ) < G2 (4.17 B), which suggests that bleaching associated with lime juice immersion caused the highest surface roughness among the samples assessed, followed by its association with apple vinegar. The highest grade value was also observed in G2 (Bleaching + Lime Juice- 67.75B), thus suggesting that lime has a higher erosive potential than vinegar $(\mathrm{G} 3=41.40 \mathrm{C})$ and immediate bleaching without associations $(\mathrm{G} 1=29.80 \mathrm{~A})$.

The enamel is a highly mineralized tissue formed by densely compacted hydroxyapatite crystals and a small amount 
of water and organic matter. It mainly presents a prismatic structure, considering its outermost layer is aprismatic and, to a certain extent, resistant to erosion. However, an osmotic process occurs in tooth enamel, in which there is a continuous water displacement from its surface toward the dentin, capable of transporting acid molecules that cause demineralization (Liporoni et al., 2020). Therefore, the erosive demineralization of enamel is a process that starts with a partial loss of hydroxyapatite crystals from the surface and, continuing with the acid insult, there is a substantial mineral loss by the diffusion of acid through the structure (Liporoni et al., 2020).

Several factors affect the erosive potential of substances and consequently the level of tooth structure loss. These are physical and chemical properties such as the type of acid, titratable acidity, chelating potential, molecule size, exposure time, temperature, adhesion, the concentration of the solution, and $\mathrm{pH}$, besides the condition itself in terms of roughness and permeability of the enamel when exposed to the acidic substance (Zohoori, 2020; Maltarollo et al., 2020).

Hence, an enamel porous surface, such as the one presented by the initial erosion lesion caused by bleaching, not only presents irregularities that increase the contact surface area with the acid but also shows a larger exposed damaged area, which increases enamel susceptibility to erosive wear (Lussi et al., 2019; Azrak et al., 2010). Therefore, this is the subsequent challenge to bleaching, through the immersion in acidic substances such as citric and acetic acids, which can easily diffuse through the enamel structure and increase the activity of the erosive challenge, increasing volumetric roughness and structure loss (George et al., 2015), thus corroborating the observations of this study by the results exposed in Tables 3 and 4. Additionally, the higher roughness and structure loss presented by the lime juice when compared to apple vinegar may be explained by the high volatility of the acetic acid in it, which when evaporates, increases the $\mathrm{pH}$ of the solution and consequently decreases the erosive potential (Dey et al., 2016; Liporoni et al., 2020).

Due to the known perfusion potential of the molecules through the tooth enamel, it is considered that, in the present study, there might have been some degree of demineralization in deeper layers of the enamel, in the non-exposed portion of the samples. However, non-contact 3D profilometry reaches a maximum depth of $0.1 \mathrm{~nm}$ (Baryshev et al., 2013), thus it analyzes only the surface, which in the non-exposed portion was sufficiently protected from the erosive challenges imposed on the samples.

\section{Conclusion}

Immediate bleaching with a 35\% hydrogen peroxide bleaching gel promoted significant changes in the surface topography of bovine enamel. The immersion in acidic beverages after tooth bleaching increased the surface roughness of bovine enamel and the height of the grade formed between treated and untreated surfaces, showing structure loss in the region exposed to the erosive challenges. These changes were more significant when using lime juice.

\section{References}

Abouassi, T., Wolkewitz, M., \& Hahn, P. (2011). Effect of carbamide peroxide and hydrogen peroxide on enamel surface: an in vitro study. Clin Oral Investig, 15, 673-680.

Alexandria, A. K., Valença, A. M. G., Cabral, L. M., \& Maia, L. C. (2017). Fluoride Varnishes against Dental Erosion Caused by Soft Drink Combined with Pediatric Liquid Medicine. Braz Dent J, 28(4), 482-48.

Alexandria, A. K., Vieira, T. I., Pithon, M. M., da Silva Fidalgo, T. K., Fonseca-Gonçalves, A., Valença, A. M., Cabral, L. M., \& Maia, L. C. (2017). In vitro enamel erosion and abrasion-inhibiting effect of different fluoride varnishes. Arch. Oral Biol, 77, 39-43.

Ayres, A. P. A., Berger, S. B., Carvalho, A. O., \& Giannini, M. (2016). Effects of hydrogen peroxide on dental permeability. Rev Bras Odontol, 73(2), 96-100.

Azrak, B., Callaway, A., Kurth, P., \& Willershausen, B. (2010). Influence of bleaching agents on surface roughness of sound or eroded dental enamel specimens. J Esthet Restor Dent, 22, 391-399.

Baryshev, S. V., Erck, R. A., Moore, J. F., Zinovev, A. V., Tripa, C. E., \& Veryovkin, I. V. (2013). Characterization of surface modifications by white light interferometry: applications in ion sputtering, laser ablation, and tribology experiments. J Vis Exp, 27(72), e50260. 
Bersezio, C., Martin, J., Peña, F., Rubio, M., Estay, J., Vernal, R., Junior, O. O., \& Fernández, E. (2017). Effectiveness and Impact of the Walking Bleach Technique on Esthetic Self-perception and Psychosocial Factors: A Randomized Double-blind Clinical Trial. Oper Dent, $42(6), 596-605$.

Canto, F. M. T., Alexandria, A. K., Magno, M. B., Silva, E. M., \& Maia, L. C. (2020). Topography and microhardness changes of nanofilled resin composite restorations submitted to different finishing and polishing systems and erosive challenge. Pesqui Bras Odontopediatria Clín Integr, 20, e4812.

Costa, C. J. M. (2013). Análise Topológica Experimental por Perfilometria Cíclica Indutiva de Superfícies de Paredes Estruturais. Natal (Rio Grande do Norte): s.n.

Dey, S., Pandey, V., Kumar, A., Awasthi, N., Sahu, A., \& Pujari, S. C. (2016). In vitro comparison of impact of different bleaching agents on the microhardness of enamel. J Contemp Dent Pract, 17(3), 258- 262.

Fernandes, R. A., Strazzi-Sahyon, H. B., Suzuki, T. Y. U., Briso, A. L. F., \& Dos Santos, P. H. (2020). Effect of dental bleaching on the microhardness and surface roughness of sealed composite resins. Restor Dent Endod, 45(1), 12.

George, L., Baby, A., Dhanapal, T. P., Charlie, K. M., Joseph, A., \& Varghese, A. A. (2015). Evaluation and comparison of the microhardness of enamel after bleaching with floride free and floride containing carbamide peroxide bleaching agents and post bleaching anticay application: an in vitro study. Contemp Clin Dent, 6(Suppl 1), 163-166.

Kanzow, P., Wegehaupt, F. J., Attin, T., \& Wiegand, A. Etiology and pathogenesis of dental erosion. Quint. Intern, 47(4), 275-278.

Kutuk, Z. B., Ergin, E., Cakir, F. Y., \& Gurgan, S. (2019). Effects of in-office bleaching agent combined with different desensitizing agents on enamel. J Appl Oral Sci, 27, e20180233.

Liporoni, P. C. S., Wan Bakar, W.Z., Zanatta, R. F., Ambrosano, G. M., Aguiar, F. H. B., \& Amaechi, B. T. (2020). Influence of Erosion/Abrasion and the Dentifrice Abrasiveness Concomitant with Bleaching Procedures. Clin Cosmet Investig Dent, 12, 101-109.

Lussi, A., Samira, H. J. S., Megert, B., Carvalho, T. S., \& Baumann, T. (2019). The erosive potential of different drinks, foodstuffs and medicines a vade mecum. Swiss Dent J, 129(6), 479-487.

Maltarollo, T. H., Pedron, I. G., Medeiros, J. M. F., Kubo, H., Martins, J. L., \& Shitsuka, C. (2020). The dental erosion is a problem!.Research, Society and Development, 9(3), e168932723.

Mondelli, R. F. L., Gabriel, T. R. C. G., Rizzante, F. A. P, Magalhães, A. C., Bombonatti, J. F. S., \& Ishikiriama, S. K. (2015). Do different bleaching protocols affect the enamel microhardness? Eur J Dent, 9(1), 25-30.

Mosaico, G., \& Casu, C. (2018). Erosão dentária particular. Pan Afr Med J, 30, 190.

Mushashe, A. M., Coelho, B. S., Garcia, P. P., Rechia, B. N., da Cunha, L. F., Correr, G. M., \& Gonzaga, C. C. (2018). Effect of different bleaching protocols on whitening efficiency and enamel superficial microhardness. J Clin Exp Dent, 10(8), 772-775.

Oliveira, G. C., Tereza, G. P. G., Boteon, A. P., Ferrairo, B. M., Gonçalves, P. S. P., Silva, T. C. D, Honório, H. M., \& Rios, D. (2017). Susceptibility of bovine dental enamel with initial erosion lesion to new erosive challenges. PLoS One, 12(8), e0182347.

Omar, F., Ab-Ghani, Z., Rahman, N. A., \& Halim, M. S. (2019). Nonprescription Bleaching versus Home Bleaching with Professional Prescriptions: Which One is Safer? A Comprehensive Review of Color Changes and Their Side Effects on Human Enamel. Eur J Dent, 13(4), 589-59.

Rios, D., Ionta, F. Q., Rebelato, R., Jordão, M. C., Wang, L., Magalhães, A. C., \& Honório, H. M. (2018). The effect of aspartame and pH changes on the erosive potential of cola drinks in bovine enamel: An in vitro study. J Clin Exp Dent, 10(9), 933-937.

Sa, Y., Sun, L., \& Wang, Z. (2013). Effects of two in-office bleaching agents with different pH on the structure of human enamel: an in situ and in vitro study. Oper Dent, 38, 100-110.

Tin-Oo, M. M., Saddki, N., \& Hassan, N. (2011). Factors influencing patient satisfaction with dental appearance and treatments they desire to improve aesthetics. BMC Oral Health, 11, 6.

Vieira, I., Vieira-Junior, W. F., Pauli, M. C., Theobaldo, J. D., Aguiar, F. H., Lima, D. A., \& Leonardi, G. R. (2020). Effect of in-office bleaching gels with calcium or fluoride on color, roughness, and enamel microhardness. J Clin Exp Dent, 12(2), 116-122.

Xing, Q., \& Xuedong, Z. (2020). The etiology, diagnosis and prevention strategies of acid etching. Chinese Journal of Stomatology, 55(5), 289-295.

Yassen, G. H., Platt, J. A., \& Hara, A. T. (2011). Bovine teeth as substitute for human teeth in dental research: a review of literature. J Oral Sci, 53(3), 273-82.

Zanet, C. G., Araújo, R. M., Valera, M. C., \& Pucci, C. R. (2009). Refrescos Ácidos: Dissolução do Esmalte. Odonto, 18(35), 14-23.

Zohoori, F. V., \& Duckworth, R. M. (eds). (2020). The Impact of Nutrition and Diet on Oral Health. Monogr Oral Sci, 28, 91-98. 